\title{
Editorial
}

\section{An introductory review to the special issue: Shrinking cities and towns: Challenge and responses}

\author{
URBAN DESIGN International (2013) 18, 1-5. doi:10.1057/udi.2012.36
}

\section{Introduction}

Cities and towns facing sustained population loss are being researched and discussed more than ever before. Once the focus of a relatively small group of architects and urban designers in Europe, these cities and towns are now being studied by scholars across the world. In a range of contexts - from a large, iconic city like Detroit to a small village in Japan (described by Thomas Feldhoff in this issue) - this phenomenon is being observed in unexpected places, and far more frequently than once imagined.

A wider population is engaging in this, and discussions of the future of these communities are slowly entering the public discourse through diverse channels. In some places, the population is being engaged directly through a planned process of community engagement. Other means have included exhibitions, news reports, magazine articles, blogs and most recently, a spate of documentary films on urban decline.

\section{The Development of a Concept}

The first large-scale effort that brought wide attention to the topic was the Shrinking Cities project, which was active between 2002 and 2008 and sponsored by Germany's Federal Cultural Foundation in co-operation with the Leipzig Gallery of Contemporary Art, the Bauhaus Dessau Foundation and the magazine $A R C H+$. Under the direction of architect Philipp Oswalt, the project was very influential in identifying challenges and beginning a dialog on cities facing dramatic population loss.

One of the outcomes of this project was a pair of exhibitions, Shrinking Cities I and II, (Oswalt, 2005, 2006) shown in Berlin, Halle/Saale and Leipzig in 2004-2005. Following the success of these exhibitions in Germany, the German Federal Cultural Foundation sponsored it in several international sites. Between 2006 and 2008, selections from the exhibition contributions were on view in the United
States, Britain, Japan and Russia. This exhibition made a stop at Eero Saarinen's campus at Cranbrook Academy of Art, a stone's throw from perhaps the most widely discussed shrinking city in the world, Detroit, a discussion that we continue in this issue with Anirban Adhya's contribution. In 2006, Philipp Oswalt and Tim Rieniets produced the Atlas of Shrinking Cities (2006). In December that year, the first entry on Shrinking Cities appeared on Wikipedia.

The exhibitions, and to a lesser degree, the atlas, began a public conversation about shrinking cities. It educated a wide range of people, cultivated interest in the ideas and added a new term to the lexicon. It drew attention to the many possible causes of urban shrinkage, the challenges caused by population decline and large-scale vacancy, and suggested a series of responses, proposed mostly by architects. It would be hard to overestimate the importance of this project in drawing attention to the phenomenon of cities facing sustained population loss and giving the phenomenon a name.

Through paths like these, and through a number of other, more public means, such as newspaper and magazine articles, television reports, blogs, and most recently, documentary films, the discussion of shrinking cities is reaching a much wider audience. Films, such as Requiem for Detroit? (2010), Sometimes City (2011), the Pruitt-Igoe Myth (2011) and Detropia (2012), have brought increased attention and a wider audience to the challenges these cities face.

Although the first references to shrinking cities in this era came from Europe, US cities were facing similar challenges, where a parallel discussion was developing. Old manufacturing cities, so called "Rust Belt" cities, such as Youngstown, Ohio and Flint, Michigan were beginning to address the challenges of steep population loss and economic decline. In 2002, Youngstown began the process of developing a comprehensive plan that dealt explicitly with the challenges of shrinkage, resulting in the much-acclaimed Youngstown 2010 plan. 
The Genesee County Land Bank (which includes Flint), established in 2004, drew a lot of attention for an early and innovative attempt to develop a system to acquire and get a clear title to abandoned properties (Ryan, 2012b). In 2004, the Cleveland Urban Design Collaborative launched the Shrinking Cities Institute and has since conducted a number of activities, including charrettes, exhibitions and research initiatives, to further the discussion on population decline and urban vacancy not only in Cleveland, but also more generally.

Since then, there have been several articles and books that have contributed to the discussion and our understanding of shrinking cities. Beginning in 2007, the Institute of Urban and Regional Development (IURD) at the University of California, Berkeley, began a monograph series on shrinking cities. (Pallagst 2007, 2008) that same year, a special issue of Progress in Planning (Hollander et al, 2009) on emerging research agendas drew attention to the need for planning to address shrinking cities. Important work has also been published through non-traditional outlets such as design centers - for example, Kent State University's Cleveland Urban Design Collaborative. Caru Bowns' paper on small towns in Pennsylvania is linked to work being done by the Hamer Center for Community Design at Pennsylvania State University. The University of Houston Design Center directed by Raphael Longoria and Susan Rogers shows a particular interest in shrinkage at the neighborhood level within a growing market.

A number of noteworthy books published in the last couple of years have added greatly to the discussion of shrinking cities in the United States, and have concurrently added to the terminology. Justin Hollander's book, Sunburnt Cities (2011), expanded the geography of shrinking cities in the United States from the industrial heartland to include cities in southern states such as Florida, Arizona and Nevada. In this issue, Hollander explores the physical changes and analyzes the ongoing response to the declining population in a small fishing village, New Bedford, MA. Brent Ryan's book, Design After Decline (2012a) was a detailed examination of urban design and planning efforts at rebuilding Philadelphia and Detroit, with a focus on the physical changes in the fabrics of these two cities. Margaret Dewar and June Thomas's The City After Abandonment (2012) brought together current thinking on a number of different aspects of shrinking cities, including the dramatic experience of New Orleans following Hurricane Katrina. And Allan Mallach's Rebuilding America's Legacy Cities (2012) focused on strategies for shrinking cities in America's industrial belt.

A quick examination of recent academic conferences where shrinking cities have been discussed shows a widening of disciplines engaged in this topic. Conferences organized by the Association of Collegiate Schools of Planning (2010 onwards), the Association of Collegiate Schools of Architecture (2010), the Urban Affairs Association (2012), the Society of Architectural Historians (2012), the Association of American Geographers (2012) and the International Geographical Congress (2012) have all hosted sessions on shrinking cities. A review of the participants in many of these panels shows that they have brought together researchers from different disciplines, for example, urban planners at a conference for geographers or historians. Justin Hollander, was one such example, presenting work at the Society of Architectural Historians held in Detroit earlier this year, suggesting the possibilities for greater cross-boundary sharing and opportunities for interdisciplinary thinking. The ideas Hollander presented at that conference form the core of his contribution to this special issue. Similarly, Gert-Jan Hospers and Thomas Feldhoff, both contributors to this issue, are examples of scholars reaching audiences across disciplinary boundaries, teaching in a School of Management and School of Interdisciplinary Studies, respectively, and publishing now in a journal on urban design.

Long accused of training students to work in contexts of growth rather than in the realities of population and economic decline, academic departments in the United States are also slowly making a shift. Several established universities in the US industrial midwest and northeast, such as MIT, Tufts, Cleveland State University and the University of Michigan, offer courses or studios that focus on shrinking cities, as do many smaller, lower-profile institutions like our respective academic homes, Bowling Green State University and the University of Toledo (Shetty and Luescher, 2010a, b).

There have been several new university-based initiatives as well. The best known of these is the newly launched The Urban Shrinkage, Adaptation, and Resilience Initiative hosted by the Centre for Urban and Regional Studies within the School of Geography, Earth, and Environmental Sciences at 
the University of Birmingham (UK). The initiative is conceived as an international multidisciplinary forum to bring together urban scholars, activists and practitioners 'working on new ways and means of building resilient and resourceful cities urban living environments capable of withstanding and successfully responding to the immediate shocks and long-standing effects of the economic crisis, demographic shift, and human-induced climate change' (Mykhnenko, 2012). Academic journals are also paying increasing attention. For example, recent special issues of the International Journal of Urban and Regional Research (IJURR, Martinez-Fernandez et al, 2012) and Built Environment (2012) extensively covered current efforts to theorize and bring greater specificity to the study of shrinking cities.

\section{Scale}

In a world where borders in many ways seem to matter less and less to the flow of information or trends in population change (Kabisch et al, 2012), a recent well-regarded study raises questions of scale and makes a case for a focus on regional geographies. The report by Skidmore, Owings and Merrill (SOM) on a vision for the Great Lakes and St. Lawrence River region identifies a number of shrinking cities such as Milwaukee, Detroit, Cleveland and Buffalo (Skidmore et al, 2012). Caru Bowns and Thomas Feldhoff draw attention to the regional scale in their papers in this issue, focusing on regions in rural Pennsylvania and rural Japan, respectively.

This is not to suggest that patterns are uniform across a region. Digging a little deeper, one finds in the cities identified in the SOM report, each is located within a metropolitan region that is expected to expand its physical footprint substantially in the next decade. For example, by 2025, the Milwaukee region is estimated to add 287 square miles, the Detroit region, 311 square miles, the Cleveland region, 355 square miles (Skidmore et al, 2012).

Even as we focus on shrinking cities, it seems, urban sprawl at the metropolitan level continues unabated. Yet there is no predictable shrinking core-growing suburbs pattern at this scale. Sprawl, out-migration, large-scale economic change and disinvestment, among other factors, have resulted in very uneven patterns of growth and shrinkage in metropolitan areas. For example, many innerring or first suburbs are experiencing sustained population loss. Shedding light on this relatively understudied type of shrinking city, Adhya's paper in this issue focuses on one such case, the Detroit suburb of Warren, and examines the challenges and responses to population loss at the local and regional scales. The pattern of growth and shrinkage can be uneven within a city as well - even as a city grows over time, certain neighborhoods shrink - and Longoria and Rogers draw attention to three such neighborhoods in Houston.

Small towns are not immune either. Using an old fishing village, New Bedford, Massachusetts, as his case study, Hollander examines the physical dimensions of population loss at a very finegrained scale, documenting changes at the block level. Caru Bowns looks at a group of small towns in rural Pennsylvania that are coping with population loss. Across the world, Feldhoff uses rural Japan as his location to examine responses to villages with shrinking and aging populations as the young move to cities in search of work.

\section{Policy}

Shrinking communities across the world are planning for their futures in very different policy environments, and the contributions to this theme issue shed light on many of them. There are some broad patterns - in countries of the European Union as well as in Japan, there are examples of federal support for efforts to understand and address the challenges of sustained population loss and economic decline, and recognition of the need to consider policy responses at the regional scale, as Hospers, Zingale and Riemann and Feldhoff point out in this issue. European Union countries, in general, have been proactive. For example, the support for sustainable cities in general, including work on shrinking cities, is supported across national borders as well with programs like URBACT, jointly financed by the European Regional Development Fund of the European Union and its member states.

In contrast, American responses have largely, though not exclusively, been at the local level. In some cities, such as Detroit and Youngstown, the leadership for large-scale planning and urban design efforts has come from mayors at the same time as non-profit groups were working on these issues at the neighborhood level, as Adhya illustrates in his contribution. Overall, though, elected officials, their professional staff and civic 
leaders in a wide range of cities across the world are acknowledging and planning for a future with far fewer residents, and in doing so, contributing to a shift away from an entrenched growthoriented planning paradigm (Mallach, 2012). University-based community design centers have been active in the discussion. The Cleveland URBAN DESIGN Collaborative was an early forerunner and our contributors Longoria and Rogers, and Bowns, draw attention to examples in Houston and Pennsylvania where their research has specific policy implications.

Interest is evident in the private sector as well. Urban shrinkage has drawn the attention of established think tanks like the Brookings Institution that have produced research to help frame urban policy. Other actors are slowly entering the policy discussion. For example, the world of business has started paying attention to population trends in cities as these enter the business consulting sector's assessment of investment strategies (Dobbs et al, 2011).

\section{Conclusion}

A collection of seven articles is simply not a big enough forum to examine all the facets presented by shrinking cities and towns. The experience of sustained population loss may be a shared one; this hides great variation in the causes, patterns and responses in different places (Grossmann et al, 2012). For example, many old industrial centers in Western European countries, postsocialist Europe and the United States appear to share similar economic and population trajectories, but even within Europe there is great variation (Bontje and Musterd, 2012). Smaller places, whether mining towns in Korea or villages in Japan, also share the experience of population and economic decline, yet face very different challenges. The experiences of shrinking cities and towns may be broadly similar but turn out to be very particular to local contexts.

The complexity of patterns of growth and shrinkage plays out on the landscape in unpredictable ways. It can occur at large scales Cyprus is an example, at the metropolitan level (Hanlon, 2009) and at scales smaller than that. Occasionally, the shrinkage can be sudden and drastic as we saw in New Orleans, resulting in a different physical outcome (Ehrenfuecht and Nelson, 2012) Growing and shrinking neighborhoods within a city, often abutting or in close proximity to each other, can produce a perforated urban fabric in cities ranging from Dresden to Houston (Beeck, 2011; Wiechmann and Pallagst, 2012; Longoria and Rogers, Exodus within an Expanding city in this issue), producing another set of challenges for planners and others working at the local level.

The design and planning responses to these many patterns of decline vary greatly. Whether land banks, community gardens, building demolition programs or an abandoned factory turned into a giant play structure, communities have used a wide range of tools to confront physical decline. These responses have arisen from different levels of government - broadly at the federal level in Europe, and at the local level in the United States. Korea and Japan, two other countries where shrinking cites have been studied, also show federal-level policy involvement. At the same time, policy intervention in the United States has shown differing levels of local government involvement, for example, ranging from a large-scale attempt currently underway in Detroit to a series of under-the-radar efforts in Cleveland referenced in Zingale and Riemann. However, shrinking cities do not present just physical challenges. Questions of equity, participation, sustainability and dealing with climate change are only some of the many factors that will influence policy choices, and that need more attention.

The papers in this special issue each deal with urban design and planning in communities facing sustained population loss. Collectively, they describe a number of characteristics of these places; among them are the immense range of reasons for shrinking communities across the world, the diverse patterns of change, the different scales at which this change can be observed, the differences in the levels of government at which public policy is enacted, the many structures of governance, the challenge of husbanding resources, the many actors and institutions interested in addressing these issues, the actual plans to confront shrinkage, and the role of residents in these communities. In doing so, they shed light on the complexity of the challenges and responses in these shrinking communities.

\section{References}

Beeck, S. (2011) Shrinking Cities in East Germany. Maastricht, The Netherlands: Boekenplan. 
Bontje, M. and Musterd, S. (eds.) (2012) Understanding shrinkage in European regions (special issue). Built Environment 38(2): 153-161.

Dewar, M. and Thomas, J.M. (eds.) (2012) The City After Abandonment. Philadelphia, PA: University of Pennsylvania Press.

Dobbs, R., Remes, J. and Smit, S. (2011) The world's new growth frontier: Midsize cities in emerging markets. Retrieved from http://www.mckinseyquarterly.com/The worlds_new_growth_frontier_Midsize_cities_in_emerging markets_2775.

Ehrenfuecht, R. and Nelson, M. (2012) Recovery in a shrinking city: Challenges to right-sizing post-Katrina New Orleans. In: M. Dewar and J.M. Thomas (eds.) (2012) The City After Abandonment. Philadelphia, PA: University of Pennsylvania Press.

Ewing, H. and Grady, R. (dir.) (2012) Detropia, Loki Films, LLC, New York.

Grossmann, K., Beauregard, R., Dewar, M. and Haase, A. (2012) European and US perspectives on shrinking cities. Urban Research \& Practice 5(3): 360-363.

Hanlon, B. (2009) Once the American Dream: Inner-ring Suburbs of the Metropolitan United States. Philadelphia, PA: Temple University Press.

Hollander, J.B. (2011) Sunburnt Cities: The Great Recession, Depopulation and Urban Planning in the American Sunbelt. London/New York: Routledge.

Hollander, J.B., Pallagst, K., Schwarz, T. and Popper, F. (2009) Planning shrinking cities. Progress in Planning 72(3): 223-232.

IJURR. (2012) Shrinking cities: Urban challenges of globalization. International Journal of Urban and Regional Research 36(2): 213-414.

Kabisch, N., Haase, D. and Haase, A. (2012) Urban population development in Europe, 1991-2008: The examples of Poland and the UK. International Journal of Urban and Regional Research 36(6): 1127-1364.

Longoria, R. and Rogers, S. (2012) Exodus within an expanding city: The case of Houston's historic African-American communities. Urban Design International, advance online publication December 12, doi: 10.1057/udi.2012.28.

Mallach, A. (2012) Rebuilding America's Legacy Cities: New Directions for the Industrial Heartland. North Charleston, SC: CreateSpace Independent Publishing Platform.

Martinez-Fernandez, C., Audirac, I., Fol, S. and CunninghamSabot, E. (2012) Shrinking cities: Urban challenges of globalization. International Journal of Urban and Regional Research 36(2): 213-225.

Mykhnenko, V. (ed.) (2012) Issue 1: The Urban Shrinkage, Adaptation, and Resilience Initiative. Birmingham, UK: Centre for Urban and Regional Studies, School of Geography, Earth and Environmental Sciences, University of Birmingham.
Oswalt, P. (ed.) (2005) Shrinking Cities, Vol. 1. Ostfildern-Ruit, Germany: Hatje Cantz Verlag.

Oswalt, P. (ed.) (2006) Shrinking Cities, Vol. 2. Ostfildern-Ruit, Germany: Hatje Cantz Verlag.

Oswalt, P. and Rieniets, T. (eds.) (2006) Atlas of Shrinking Cities. Ostfildern-Ruit, Germany: Hatje Cantz Verlag.

Pallagst, K. (2007) The Future of Shrinking Cities: Problems, Patterns and Strategies of Urban Transformation in a Global Context. Berkeley, CA: IURD Monograph Series, Institute of Urban and Regional Development, UC Berkeley.

Pallagst, K. (2008) Shrinking cities: Planning challenges from an international perspective. In: S. Rugare and T. Schwarz (eds.) Cities Growing Smaller. Cleveland, OH: Cleveland Urban Design Collaborative, pp. 6-16.

Friedrichs, C. (dir.) (2011) Pruitt-Igoe Myth: An Urban History, Unicorn Stencil Documentary Films.

Temple, J. (dir.) (2010) Requiem for Detroit? British Broadcasting Corporation (BBC), UK.

Ryan, B. (2012a) Design After Decline How America Rebuilds Shrinking Cities. Philadelphia, PA: University of Pennsylvania Press.

Ryan, B. (2012b) Shrinking-city urban form as a determinant of urban policy: The case of flint, Michigan, USA. Perm, Russia: 48 ISOCARP Congress, The International Society of City and Regional Planners.

Skidmore, Owings and Merrill. (2012) Recognizing a global resource: Vision for the great lakes and St. Lawrence region. Retrieved from http://www.som.com/content.cfm/recognizing_a_global_resource.

Shetty, S. and Luescher, A. (2010a) When economic growth is no longer the norm: Teaching urban design in a time of transformation. Archnet-IJAR 4(2/3): 139-157.

Shetty, S. and Luescher, A. (2010b) Interdisciplinarity in urban design: Erasing boundaries between architects and planners in urban design studios. Open House International 35(3): 87-97.

Jarmusch, T. (dir.) (2011) Sometimes City.

Wiechmann, T. and Pallagst, K. (2012) Urban shrinkage in Germany and the USA: A comparison on transformation patterns and local strategies. International Journal of Urban and Regional Research 36(2): 261-280.

Andreas Luescher Department of Architecture and Environmental Design, Bowling Green State University, OH, USA E-mail: aluesch@bgsu.edu

Sujata Shetty
Department of Geography and Planning,
University of Toledo, OH, USA
E-mail: Sujata.Shetty@utoledo.edu

